\title{
ANALISIS HASIL BELAJAR BIOLOGI SISWA KELAS X PROGRAM IPS: DAMPAK MODEL PEMBELAJARAN PROBLEM POSING
}

\author{
Siti Aisyah ${ }^{1}$, Eka Lokaria $^{2}$, Harmoko $^{3 *}$ \\ ${ }^{1,2,3}$ Pendidikan Biologi STKIP PGRI Lubuklinggau \\ "Email: putroharmoko@gmail.com
}

Received: Oktober $3^{\text {th }}, 2019$. Accepted: November $2^{\text {nd }}, 2019$. Published: December $29^{\text {th }}, 2019$

\begin{abstract}
This study aims to determine the effect of the problem posing learning model on the learning outcomes of biology class X IPS students at Tugumulyo State High School. The research method used is pure experimentation. Data collection techniques in research using tests. Data analysis techniques with steps: normality test, homogeneity test, and t test. The results of preliminary observations, it is known that the average value of the learning outcomes of the students of Class X IPS daily tests is still low due to the lack of student activity in asking or responding to teacher questions, students lack the desire to be actively involved in the learning process, and students tend to only wait for material delivered by the teacher without the initiative to find and explore information independently. The results of the post-test data analysis using the t-test, obtained a tcount of 4.59. This result is compared with the table value at the 5\% significance level of 1.67. This shows that the value (4.59)> (1.67), then there is the influence of the problem posing learning model on the learning outcomes of biology students in class X IPS of Tugumulyo State High School.
\end{abstract}

Keywords: Study Results Biology; Problem Posing; Virus.

\begin{abstract}
Abstrak
Penelitian ini bertujuan mengetahui pengaruh model pembelajaran problem posing terhadap hasil belajar biologi siswa kelas X IPS SMA Negeri Tugumulyo. Metode penelitian yang digunakan eksperimen murni X IPS SMA Negeri Tugumulyo tahun ajaran 2017/2018 sebanyak 135 orang yang terdiri dari 4 kelas. Teknik pengumpulan data dalam penelitian menggunakan tes. Teknik analisis data dengan langkah-langkah: uji normalitas, uji homogenitas, dan uji t. Hasil analisis data post-test dengan menggunakan uji-t, diperoleh nilai $t_{\text {hitung }}$ sebesar 4,59. Hasil ini dibandingkan dengan nilai ttabel pada taraf signifikan $5 \%$ yaitu 1,67 . Hal ini menunjukkan bahwa nilai $t_{\text {hitung }}(4,59)>t_{\text {tabel }}(1,67)$, maka ada pengaruh model pembelajaran problem posing terhadap hasil belajar biologi siswa kelas X IPS SMA Negeri Tugumulyo.
\end{abstract}

Kata Kunci: Hasil Belajar Biologi; Problem Posing; Virus.

\section{PENDAHULUAN}

Pembelajaran biologi di sebagai wahana menumbuhkan kemampuan berpikir dan memecahkan masalah dalam kehidupan sehari-hari (Setyorini, Sukiswo, dan Subali 2011a; Artikasari dan Saefudin 2017). Pembelajaran biologi tidak hanya mengacu pada kemampuan intelektual siswa, melainkan keaktifan dan keterlibatan siswa secara langsung saat suatu proses pembelajaran untuk membangun pengetahuannya sendiri. Kegiatan pembelajaran biologi di sekolah seharusnya dilakukan dengan melibatkan peserta didik di dalamnya. Siswa dituntut untuk aktif dan berpartisipasi secara nyata menerapkan apa yang telah dipelajarinya 
dari pengajar dengan bertanya, berpendapat, mengerjakan tugas, berlatih, atau mencoba (Karyanti dan Komarudin 2017). Sedangkan menurut Slameto, pengajar mempunyai tanggung jawab atas terselenggaranya proses belajar yang sesuai dengan tujuan pembelajaran sehingga mampu mempengaruhi hasil belajar siswa menjadi lebih optimal (Prastawa 2013)

Kurangnya aktivitas siswa dilihat dari perilaku siswa dalam belajar yang tidak memiliki keberanian dalam bertanya ataupun merespon pertanyaan pengajar saat belajar. Selain itu, siswa cenderung hanya menunggu materi yang disampaikan oleh pengajar tanpa adanya inisiatif untuk mencari dan menggali sendiri informasi secara mandiri sebelum materi tersebut disajikan (Agustiana, Supriadi, dan Komarudin 2019). Hal ini sesuai dengan pendapat Slameto yang menyatakan bahwa banyak siswa gagal atau tidak mendapat hasil yang baik dalam pelajarannya karena mereka tidak mengetahui cara-cara belajar yang efektif (Zaura dan Zubaidah 2018; Cahyasari 2016; Rufaidah 2015; Berutu 2013; Kurniawan 2013). Kebiasaan siswa yang cenderung hanya menunggu materi yang disampaikan oleh pengajar membuat siswakesulitan memahami konsep-konsep yang dipelajari, akhirnya mengakibatkan hasil belajar siswa tidak sesuai dengan yang diharapkan.

Salah satu alternatif untuk. mengatasi permasalahan tersebut dengan menggunakan model pembelajaran yang dapat membuat siswa aktif serta menyenangkan dalam proses pembelajaran, yaitu model pembelajaran problem posing (Ngaeni dan Saefudin 2017; Suryani, Saputro, dan Martini 2015). Model pembelajaran problem posing sering juga diartikan sebagai kegiatan pembelajaran yang membantu siswa untuk menyelesaikan masalah berbentuk soal yang berkaitan dengan materi yang sedang dipelajari untuk mencari alternatif pemecahan yang masih relevan (Persada 2014; Murniati, Candiasa, dan Kirna 2013).

Penggunaan model pembelajaran problem posing diharapkan dapat membantu siswa memahami masalah yang sedang dikerjakan dan dapat meningkatkan kemampuannya dalam pemecahan masalah mengenai materi pelajaran biologi. Adapun kelebihan model pembelajaran problem posing adalah mendidik siswa berpikir kritis, siswa aktif dalam pembelajaran, belajar menganalisis suatu masalah, dan mendidik siswa percaya pada diri sendiri (Ngaeni dan Saefudin 2017; Kelen 2016; Astuti 2015; Permatasari, Veronica, dan Susilo 2013). Model pembelajaran problem posing membuat siswa lebih bersikap kritis, kreatif dan aktif, serta bertanggung jawab dalam belajar sehingga memudahkan siswa dalam memahami materi pelajaran yang akan mempengaruhi hasil belajar siswa untuk menjadi 
lebih baik. Beberapa penelitian yang pernah dilakukan tentang problem posing diantaranya untuk melihat pengaruhnya terhadap komunikasi matematis (Sari 2013; Persada 2014; Juano dan Pardjono 2016), terhadap berpikir kreatif (Hasfanudin dan Abdurrahman 2014), terhadap prestasi (Amiluddin dan Sugiman 2016; Muzaini 2016), terhadap kemampuan berpikir kritis (Mahmuzah 2015; Juano dan Pardjono 2016). Adapun penelitian tersebut belum mengkaji tentang adanya hasil belajar biologi khusunya pada materi virus kelas X program IPS. Tujuan dari penelitian ini yaitu untuk melihat pengaruh model pembelajaran problem posing terhadap hasil belajar biologi siswa kelas X program IPS SMA negeri Tugumulyo.

\section{METODE PENELITIAN}

Penelitian ini, terdapat dua kelompok sampel yaitu satu kelompok eksperimen yang diberi pelakuan model pembelajaran problem posing dan satu kelompok kontrol yang tidak diberi model pembelajaran problem posing. Sebelum dilakukan pre-test pada kelas eksperimen dan kontrol. Setelah perlakuan (treatment), kemudian di adakan post-test pada kelas eksperimen dan kontrol. Desain eksperimen yang digunakan berbentuk Control group pre-test pos-test menurut (Arikunto 2010) dapat digambarkan pada Tabel 1:

Tabel 1. Desain Control Group Pre-Test-Pos-Test

\begin{tabular}{cccc}
\hline Kelas & Pre-test & Treatment & Post-test \\
\hline Eksperimen & $\mathrm{O}_{1}$ & $\mathrm{X}$ & $\mathrm{O}_{2}$ \\
Kontrol & $\mathrm{O}_{3}$ & $\mathrm{Y}$ & $\mathrm{O}_{4}$ \\
\hline
\end{tabular}

Keterangan:

$\mathrm{O}_{1}$ dan $\mathrm{O}_{3} \quad$ : Pre-test di kelas dengan model pembelajaran problem posing dan tanpa model pembelajaran problem posing

$\mathrm{X} \quad$ : Perlakuan dengan model pembelajaran problem posing

Y : Perlakuan dengan tanpa model pembelajaran problem posing

$\mathrm{O}_{1}$ dan $\mathrm{O}_{3} \quad$ : Post-test di kelas dengan model pembelajaran problem posing dan tanpa model pembelajaran problem posing.

Populasi dalam penelitian ini adalah semua siswa kelas X IPS SMA Negeri Tugumulyo tahun ajaran 2017/2018 sebanyak 135 orang yang terdiri dari 4 kelas. Sampel dalam penelitian ini diambil secara acak (random) dengan menggunakan teknik simple random sampling. Populasi dalam penelitian dapat dilihat pada Tabel 2: 
Tabel 2. Populasi Penelitian

\begin{tabular}{cccc}
\hline Kelas & Laki-laki & Perempuan & Jumlah \\
\hline X IPS 1 & 19 & 16 & 35 \\
X IPS 2 & 21 & 16 & 37 \\
X IPS 3 & 16 & 17 & 33 \\
X IPS 4 & 12 & 18 & 30 \\
\hline Jumlah & 68 & 67 & 135 \\
\hline
\end{tabular}

Pengumpulan data hasil belajar dalam penelitian ini menggunakan instrumen berbentuk tes essai. Tes ini berbentuk essay yang diberikan sebanyak dua kali yaitu sebelum (pre-test) dan sesudah (post-test) yang masing-masing diberikan di kelas eksperimen dan kontrol. Hasil belajar ranah kognitif dalam materi virus melalui tes essay berjumlah 15 soal.

Pengembangan instrument dilakukan dengan membuat soal, kemudian diujicobakan dan dianalisis, yang terdiri dari: uji validitas, reliabilitas, daya pembeda dan indeks kesukaran. Soal-soal yang memenuhi kriteria akan digunakan dalam penelitian. Analisis data dalam penelitian ini dilakukan dengan langkah-langkah sebagai berikut: menentukan nilai rata-rata dan simpangan baku (standar deviasi), uji normalitas (uji chi kuadrat), uji homogenitas (uji $F$ ) dan uji hipotesis (uji-t).

\section{HASIL PENELITIAN DAN PEMBAHASAN}

\section{Hasil Penelitian}

Berdasarkan hasil perhitungan uji normalitas pre-test dan post-test semuanya dalam kategori data normal, begitu juga dengan uji homogenitas semuanya dalam kategori data homogen. Hasil belajar dengan menggunakan model pembelajaran problem posing, dapat dilihat pada Tabel 3 berikut ini:

Tabel 3. Rekapitulasi Hasil Pre-Test dan Post-Test

\begin{tabular}{lcc}
\hline \multicolumn{1}{c}{ Model pembelajaran } & Pre-test & Post-test \\
\hline Model pembelajaran problem posing & 58.6 & 62.2 \\
Tanpa model pembelajaran problem posing & 60.3 & 70.2
\end{tabular}

Untuk mempermudah membaca Tabel 1, berikut adalah grafik hasil belajar pada kelas dengan model pembelajaran problem posing dan tanpa model pembelajaran problem posing. 


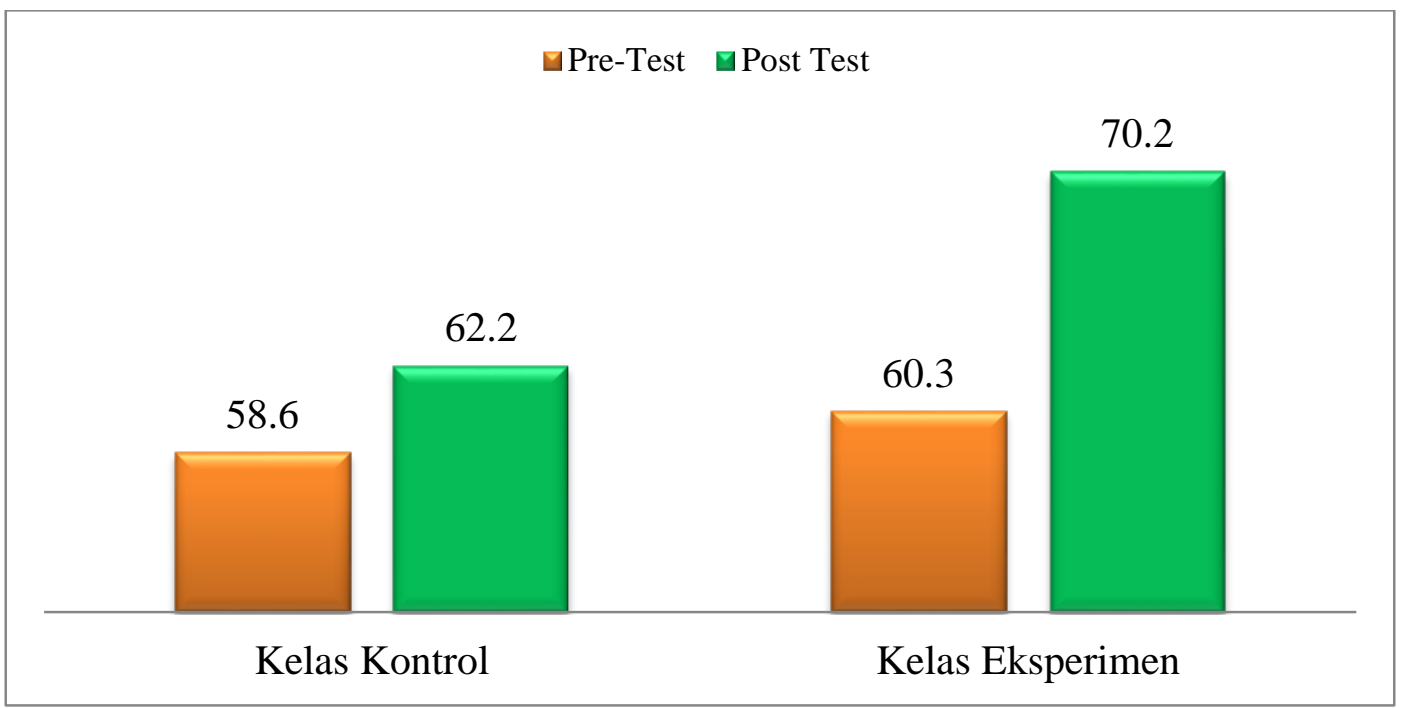

Gambar 1. Grafik Hasil Belajar pada Kelas dengan Model Pembelajaran Problem Posing dan Tanpa Model Pembelajaran Problem Posing

\section{Pembahasan}

Penelitian ini diawali dengan melakukan uji coba instrumen pada kelas XI. IPS 1 SMA Negeri Tugumulyo dengan jumlah 33 siswa pada materi virus yang bertujuan untuk mengetahui kualitas dari instrumen soal, karena suatu instrumen penelitian dikatakan mempunyai kualitas yang baik apabila memiliki persyaratan tes diantaranya melakukan uji validitas, uji reliabilitas, daya pembeda, dan tingkat kesukaran.Hasil dari uji coba instrumen tersebut diperoleh bahwa dari 15 soal uji instrumen dinyatakan valid dan digunakan sebagai alat pengumpul data penelitian.

Setelah kegiatan uji coba instrumen dilakukan, peneliti melakukan pengambilan sampel dengan cara acak atau random melalui teknik undian. Hasil undian yang dilakukan, terpilih kelas X - IPS 2 yang berjumlah 37 siswa sebagai kelas eksperimen dan kelas X - IPS 1 yang berjumlah 35 siswa sebagai kelas kontrol. Penelitian pada kelas sampel dilakukan dengan mengadakan pre-test di kelas eksperimen untuk mengetahui kemampuan awal siswa sebelum diberikan perlakuan dengan model pembelajaran Problem Posing dan pre-test di kelas kontrol. Selanjutnya dilanjutkan pemberian perlakuan dengan menerapkan model pembelajaran Problem Posing di kelas eksperimen, sedangkan pemberian perlakuan dengan menerapkan pembelajaran konvensional di kelas kontrol. Kemudian dilakukan kegiatan post- 
test dikelas eksperimen untuk mengetahui kemampuan akhir setelah diberikan perlakuan dengan model pembelajaran problem posing dan post-test di kelas kontrol.

Kegiatan tes awal (pre-test) pada kelas eksperimen dan kontrol dilakukan sebelum diberikan perlakuan dengan model pembelajaran problem posing dan pembelajaran konvensional. Hasil tes awal (pre-test) yang telah diperoleh menunjukkan bahwa tidak terdapat perbedaan nilai rata-rata antara kelas eksperimen dan kelas kontrol. Hal ini dibuktikan dari nilai rata-rata pre-test kelas eksperimen sebesar 60,30 dan nilai rata-rata pretest kelas kontrol sebesar 58,6. Setelah diketahui kedua nilai rata-rata kelompok eksperimen dan kelas kontrol dalam kegiatan tes awal (pre-test), kemudian didapat nilai simpangan baku pada kelas eksperimen sebesar 10,75 dan pada kelas kontrol sebesar 10,87.

Hasil tes awal (pre-test) pada kelas eksperimen dan kelas kontrol dalam materi virus siswa kelas X IPS SMA Negeri Tugumulyo dapat dikatakan masih rendah. Masih rendahnya hasil belajar siswa pada tes awal (Pre-test) di kelas eksperimen dan kontrol, disebabkan kurangnya pemahaman siswa tentang materi virus sehingga siswa yang tidak memahami materi terlihat kesulitan dalam mengerjakan instrumen soal yang diberikan. Hal ini menyatakan bahwa Tanpa penerapan model pembelajaran yang jelas, akan menimbulkan kesulitan bagi siswa dalam memahami konsep materi sehingga dapatlah diprediksi tujuan pembelajaran yang telah ditetapkan sulit tercapai secara optimal. Akibat yang dapat ditimbulkan adalah hasil belajar siswa menjadi kurang maksimal.

Setelah melakukan tes awal (pre-test), peneliti memberikan perlakuan (treatment) pada kelas eksperimen dan kontrol. Langkah-langkah model pembelajaran problem posing yang diterapkan dalam penelitian yaitu menyampaikan tujuan pembelajaran, membentuk kelompok yang beranggotakan 5-6 orang yang heterogen, baik kemampuan maupun jenis kelamin, membagi materi yang berbeda untuk ditanyakan, namun masih dalam konsep yang sama, meminta masing-masing peserta didik membuat satu soal dari materi yang telah dibagikan tersebut pada lembar problem posing I, masing-masing kelompok membahas dalam lembar problem posing II dan ditukar pada kelompok lain yang dilakukan berurutan, mengajukan kelompok untuk mempresentasikan hasil rangkuman yang telah dikerjakan dan membacakan soal yang tidak bisa dipecahkan dikelompoknya. Kelompok lain sebagai audiensiyang punya hak untuk menyangkal, bertanya dan memberikan masukan, sehingga pembelajaran berlangsung hangat dan pengajar hanya berperan sebagai moderator. 
Kegiatan treatment pada pertemuan pertama di kelas eksperimen dalam materi ciri-ciri virus: struktur dan ciri dengan menggunakan model pembelajaran problem posing, terdapat beberapa hambatan yang dihadapi siswa, yaitu terdapat beberapa siswa yang terlihat kesulitan membuat soal berkaitan dengan materi ciri-ciri virus: struktur dan ciri dan kesulitan kelompok membahasnya dalam lembar problem posing II. Hal ini disebabkan kurangnya kesadaran masing-masing siswa untuk bekerja sama mengerjakan tugas yang diberikan secara kelompok, karena hanya terlihat 1 atau 2 orang yang benar-benar serius mengerjakan tugas tersebut. Peneliti membentuk 7 kelompok belajar yang terdiri dari 5 kelompok sebanyak 5 orang dan 2 kelompok terdiri dari 6 orang, tetapi hanya 3 kelompok belajar (kelompok 1, 3, dan 5) yang dapat membuat dan mempresentasikan hasil rangkuman dengan baik. Kelompok belajar lainnya (kelompok 2, 4, 6, dan 7) kurang bisa bekerja sama dalam membuat dan mempresentasikan hasil rangkuman, karena mereka saling mengandalkan satu sama lain. Upaya peneliti mengatasi hal tersebut ialah mencoba memberikan pendekatan berupa motivasi kepada siswa untuk lebih meningkatkan kerja sama mereka dalam kelompok.

Kegiatan treatment pada pertemuan kedua di kelas eksperimen dalam materi kasuskasus penyakit yang disebabkan virus dan peran virus dalam kehidupan dengan menggunakan model pembelajaran problem posing, hambatan yang dihadapi, yaitu masih terdapat beberapa siswa dalam tiap kelompok yang kurang antusias dalammempresentasikan hasil rangkuman dan meresponnya, karena siswa cenderung saling mengandalkan satu sama lain untuk mempresentasikan hasil rangkuman maupu meresponnya. Peneliti juga membentuk 7 kelompok belajar yang terdiri dari 5 kelompok sebanyak 5 orang dan 2 kelompok terdiri dari 6 orang dalam kegiatan treatment pada pertemuan kedua ini. Terdapat kemajuan dalam berkerja sama membuat dan mempresentasikan hasil rangkuman, karena 6 kelompok belajar sudah dapat bekerja sama dengan baik membuat dan mempresentasikan hasil rangkuman dan hanya 1 kelompok belajar yang masih kesulitan bekerja sama membuat dan mempresentasikan hasil rangkuman sehingga guru harus memberikan pendekatan kepada siswa dalam kelompok belajar tersebut untuk meningkatkan motivasi dan kerja sama mereka dalam membuat dan mempresentasikan hasil rangkuman.

Setelah diberikan perlakuan pada kelas eksperimen dan kontrol, kemudian peneliti melakukan tes akhir (post-test) pada kelas eksperimen dan kontrol. Bila diuraikan hasil tes materi virus siswa setelah diberikan pembelajaran dengan model pembelajaran problem 
posing (Post-test) di kelas eksperimen diperoleh nilai rata-rata sebesar 73,73 yang lebih besar dari hasil tes pada kelas kontrol dengan nilai rata-rata sebesar 65,31 dengan selisih peningkatan nilai rata-rata sebesar 8,42. Hasil tes akhir (post-test) pada kelas eksperimen, diketahui bahwa siswa yang mendapat nilai $\geq 75$ dengan kriteria tuntas adalah 16 orang $(43,24 \%)$ dan siswa yang mendapat nilai $<75$ dengan kriteria tidak tuntas adalah 21 orang $(56,76 \%)$.

Hasil belajar tes akhir (post-test) pada kelas eksperimen tersebut secara klasikal baru mencapai 43,24\% atau belum mencapai 50\% dari keseluruhan jumlah siswa sebanyak 37 orang. Hal ini disebabkan sebagian besar siswa keliru dalam menjawab pertanyaan yang dimaksud pada tiap soal tes, karena siswa terlalu tergesa-gesa menjawab pertanyaan tanpa terlebih dahulu benar-benar memastikan maksud dari pertanyaan tersebut. Selain itu, siswa juga terlihat kesulitan mengaitkan pemahaman yang diketahuinya mengenai materi virus ke dalam maksud masalah yang ditanyakan pada soal sehingga siswa tidak mampu menafsirkan jawaban yang sebenarnya. Kesalahan siswa dalam menjawab soal terlihat pada pertanyaan menunjukkan struktur tubuh virus yang sebagian besar siswa terbalik antara menunjukkan bagian selubung protein (kapsid) dengan bagian asam nukleat (DNA), kesalahan siswa menjelaskan peran virus dalam kehidupan yang sebagian siswa keliru dengan cenderung menjawab tindakan-tindakan menghindari penyakit yang disebabkan kerena virus, kesalahan siswa dalam menjawab langkah-langkah memisahkan bakteri dan virus pada suatu larutan, kesalahan siswa menjelaskan tahapan-tahapan siklus litik pada replikasi virus yang cenderung siswa keliru dengan menjawab tahapan-tahapan siklus lisogenik, dan kesalahan siswa menjawab hal yang menguntungkan dari virus bagi manusia yang cenderung sebagian siswa keliru dengan menjawab peran virus dalam kehidupan.Kesulitan siswa dalam menyelesaikan soal tes tersebut dari hasil pengamatan peneliti disebabkan masih kurangnya pemahaman siswa mengenai materi virus yang dikarenakan siswa belum terbiasa mengikuti proses pembelajaran dengan model pembelajaran problem posing yang dilakukan secara berkelompok sehingga sebagain besar siswa hanya ikut-ikutan mengikuti setiap kegiatan pembelajaran dan cenderung hanya saling mengandalkan satu sama lain mengerjakan tugas.

Kemudian setelah dilakukan analisis uji normalitas data dengan menggunakan rumus chi kuadrat, diketahui bahwa nilai $\chi^{2}$ hitung data pre-test untuk kelas eksperimen adalah 6,0159 , sedangkan data post-test adalah 4,5121dengan $\chi_{\text {tabel }}^{2}$ adalah 11,070 . Hal ini menunjukkan bahwa nilai $\chi^{2}$ hitung kurang dari pada $\chi^{2}$ tabel, maka data pre-test dan post-test pada kelas 
eksperimen dinyatakan berdistribusi normal. Sedangkan uji normalitas data pada kelas kontrol, diperoleh nilai $\chi^{2}$ hitung data pre-test kelas kontrol adalah 4,8762, dan nilai $\chi^{2}$ hitung data post-test adalah 3,7315 , dengan $\chi^{2}$ tabel adalah 11,070 . Hal ini menunjukkan bahwa nilai $\chi^{2}$ hitung

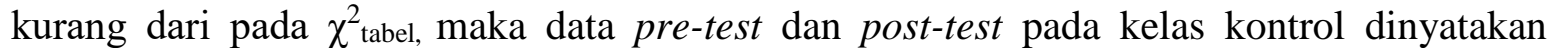
berdistribusi normal. Berdasarkan hasil uji normalitas data pada kelas eksperimen dan kontrol dapat disimpulkan bahwa semua data dalam penelitian ini berdistribusi normal.

Sedangkan hasil analisis uji homogenitas dengan menggunakan rumus uji varians $(F)$ menunjukkan bahwa varians pre-test pada kelas eksperimen dan kontrol memiliki nilai $\mathrm{F}_{\text {hitung }}$ $=1,02$ kurang dari pada $\mathrm{F}_{\text {tabel }}=1,74$. Hal ini menunjukkan bahwa varians pre-test pada kelas eksperimen dan kontrol dinyatakan homogen. Sedangkan varians post-test pada kelas eksperimen dan kontrol memiliki nilai $\mathrm{F}_{\text {hitung }}=1,03$ kurang dari pada $\mathrm{F}_{\text {tabel }}=1,74$. Hal ini menunjukkan bahwa varians post-test pada kelas eksperimen dan kontrol dinyatakan homogen. Berdasarkan hasil kedua varians kelas eksperimen dan kontrol tersebut, menunjukkan bahwa nilai $\mathrm{F}_{\text {hitung }}$ kurang dari pada $\mathrm{F}_{\text {tabel, }}$ maka varians dinyatakan homogen.

Setelah data dinyatakan normal dan variansnya homogen, kemudian dilakukan uji kesamaan dua rata-rata pre-test yang diketahui nilai $t_{\text {hitung }}=0,92$ dan $t_{\text {tabel }}=2,02$ menunjukkan bahwa $-\mathrm{t}_{\text {tabel }}<\mathrm{t}_{\text {hitung }}<\mathrm{t}_{\text {tabel}}, H_{0}$ diterima dan uji kesamaan dua rata-rata post-test yang diketahui nilai $t_{\text {hitung }}=4,59$ dan $t_{\text {tabel }}=1,67$ menunjukan bahwa $t_{\text {hitung }}>t_{\text {tabel }}$ dengan taraf kepercayaan $\alpha$ $=0,05$, berarti ada pengaruh model pembelajaran problem posing terhadap hasil belajar biologi siswa kelas X IPS SMA Negeri Tugumulyo. Penggunaan dari model pembelajaran problem posing lebih dapat meningkatkan hasil belajar siswa pada materi virus di SMA Negeri Tugumulyo daripada penggunaan pembelajaran konvensional. Model pembelajaran problem posing mampu membantu peserta didik untuk melihat permasalahan yang ada sehingga meningkatkan kemampuan menyelesaikan masalah dapat membantu siswa untuk melihat permasalahan yang ada dan yang baru diterima sehingga diharapkan mendapatkan pemahaman yang mendalam dan lebih baik, merangsang siswa untuk memunculkan ide yang kreatif dari yang diperolehnya dan memperluas bahasan/pengetahuan, siswa dapat memahami soal sebagai latihan untuk mengajukan masalah.

Hasil penelitian yang telah diuraikan di atas, relevan dengan penelitian menunjukan bahwa terdapat perbedaan peningkatan hasil belajar siswa antara kelas yang menerapkan model pembelajaran problem posing dengan kelas yang tidak menerapkan pada pokok bahasan klasifikasi makhluk hidup (Budi Antono 2017). Penelitian yang pernah dilakukan 
oleh (Baladraf 2013) dapat disimpulan bahwa penerapan problem posing berbasis Cooperative Learning pada materi sistem pernapasan berpengaruh pada hasil belajar dan minat siswa di SMP 1 Weleri Kabupaten Kendal. Penelitian (Setyorini, Sukiswo, dan Subali 2011b; Artikasari dan Saefudin 2017) menunjukkan bahwa model pembelajaran problem posing dipadu pembelajaran kooperatif model Think Pair Share (TPS) dapat meningkatkan motivasi dan hasil belajar biologi siswa kelas X IPA 5 SMAN 7 Malang. Penelitian yang pernah dilakukan oleh dapat disimpulkan bahwa problem posing meningkatkan kemampuan berpikir kreatif dan akivitas belajar (Bey 2017). Penelitian Erianti (2017) dapat disimpulan model pembelajaran problem posing dipadu Audio Visual berpengaruh terhadap keterampilan berpikir kritis dan hasil belajar siswa pada materi sistem endokrin di Mas Babun Najah Banda Aceh.

Berdasarkan hasil penelitian ini dan penelitian yang relevan tersebut, maka model pembelajaran problem posing dinyatakan mampu meningkatkan hasil belajar biologi menjadi lebih baik sebab pembelajaran problem posing merangsang memunculkan ide yang kreatif untuk memperluas pengetahuan. Para guru dapat menggunakan model pembelajaran problem posing sebagai salah satu alternatif yang dapat digunakan dalam pembelajaran materi virus atau pada materi biologi lainnya yang sesuai dengan karakteristiknya. Selain itu, upaya mengatasi hambatan-hambatan yang ditemui dengan melakukan persiapan yang lebih matang dan lebih memperhatikan siswa dalam melakukan pengamatan sehingga terkontrol dengan baik.

\section{SIMPULAN DAN SARAN}

Berdasarkan hasil penelitian dapat disimpulkan bahwa hasil analisis data post-test dengan menggunakan uji-t, diperoleh nilai thitung sebesar 4,59. Hasil ini dibandingkan dengan nilai $t_{\text {tabel }}$ pada taraf signifikan $5 \%$ yaitu 1,67 . Hal ini menunjukkan bahwa nilai $t_{\text {hitung }}(4,59)$ $>t_{\text {tabel }}(1,67)$. Maka dapat ditarik kesimpulan ada pengaruh model pembelajaran problem posing terhadap hasil belajar biologi siswa kelas X IPS SMA Negeri Tugumulyo. Adapun hasil penelitian problem posing dapat dijadikan sebagai alternative model pembelajaran supaya pembelajaran tidak monoton. Dan penelitian ini diharapkan dapat dijadikan referensi untuk peneltian selanjutnya. 


\section{DAFTAR PUSTAKA}

Agustiana, Nia, Nanang Supriadi, dan Komarudin Komarudin. 2019. "Meningkatkan Kemampuan Penalaran Matematis dengan Penerapan Pendekatan Bridging Analogy Ditinjau dari Self-Efficacy." Inovasi Pembangunan: Jurnal Kelitbangan 7 (1): 6161.

Amiluddin, Risnawati, dan Sugiman Sugiman. 2016. "Pengaruh problem posing dan PBL terhadap prestasi belajar, dan motivasi belajar mahasiswa pendidikan matematika." Jurnal Riset Pendidikan Matematika 3 (1): 100-108.

Arikunto, Suharsimi. 2010. "Prosedur penelitian."

Artikasari, Evaderika Ayu, dan Abdul Aziz Saefudin. 2017. "Menumbuh Kembangkan Kemampuan Berpikir Kreatif Matematis Dengan Pendekatan Contextual Teaching And Learning." Jurnal Math Educator Nusantara: Wahana Publikasi Karya Tulis Ilmiah di Bidang Pendidikan Matematika 3 (2): 73-82.

Astuti, Astuti. 2015. "Pengaruh Pendekatan Problem Posing dengan Model Pembelajaran Kooperatif Tipe Stad terhadap Kemampuan Komunikasi Matematis Siswa Kelas XII SMA Negeri 1 Salo Kabupaten Kampar.” Jurnal Obsesi: Jurnal Pendidikan Anak Usia Dini 1 (1): 1-11.

Baladraf, Zulfikar Ali Akbar. 2013. "Penerapan Problem Posing Berbasis Cooperative Learning Pada Pembelajaran Sistem Pernapasan Di Smp 1 Weleri Kabupaten Kendal." Universitas Negeri Semarang.

Berutu, Roni. 2013. "Hubungan minat belajar biologi dengan hasil belajar Dan pemilihan jurusan IPA pada siswa kelas X SMA Negeri 1 Salak Kabupaten Pakpak Bharat Tahun Pembelajaran 2012/2013.” UNIMED.

Bey, Anwar. 2017. "Penerapan Pembelajaran Problem Solving untuk Meningkatkan Aktivitas dan Hasil Belajar Matematika pada Materi SPLDV." Jurnal Pendidikan Matematika 4 (2): 224-39.

BUDI ANTONO, BAGUS. 2017. "Penerapan Model Pembelajaran Cooperative Integrated Reading and Composotion (circ) Pada Mata Pelajaran Mekanika Teknik Terhadap Hasil Belajar Siswa Kelas X Tpm Smk Negeri 2 Surabaya.” Jurnal Pendidikan Teknik Mesin 6 (01).

Cahyasari, Intania. 2016. "Kebiasaan Belajar dan Kemandirian Belajar Terhadap Hasil Belajar Siswa." Jurnal Pendidikan Ekonomi (JUPE) 4 (3).

Hasfanudin, Ivan, dan Abdurrahman Abdurrahman. 2014. "Pengaruh Model Pembelajaran Problem Posing Terhadap Kemampuan Berpikir Kreatif Dan Hasil Belajar.” Jurnal Pembelajaran Fisika 2 (6). 
Juano, Asterius, dan Pardjono Pardjono. 2016. "Pengaruh pembelajaran problem posing terhadap kemampuan berpikir kritis dan komunikasi matematis siswa kelas V SD." Jurnal Prima Edukasia 4 (1): 46-53.

Karyanti, Karyanti, dan Komarudin Komarudin. 2017. "Pengaruh model pembelajaran kumon terhadap pemahaman matematis ditinjau dari gaya kognitif peserta didik pada mata pelajaran matematika kelas viii smp negeri satu atap 4 pesawaran." Dalam Prosiding Seminar Nasional Matematika dan Pendidikan Matematika, 1:89-94.

Kelen, Yoseph Pius Kurniawan. 2016. "Pembelajaran Matematika dengan Pendekatan Problem Posing untuk Meningkatkan Kemampuan Berpikir Kreatif Siswa." JMPM: Jurnal Matematika dan Pendidikan Matematika 1 (1): 55-64.

Kurniawan, Fery. 2013. "Pengaruh Cara Belajar Dan Fasilitas Belajar Terhadap Prestasi Belajar Siswa Pada Mata Diklat Penyusunan Laporan Keuangan Di Kelas X Akuntansi Smk Negeri 1 Bojonegoro.” Jurnal Pendidikan Akuntansi (JPAK) 1 (3).

Mahmuzah, Rifaatul. 2015. "Peningkatan Kemampuan Berpikir Kritis Matematis Siswa SMP Melalui Pendekatan Problem Posing.” Jurnal Peluang 4 (1).

Murniati, Luh Dewi, I. Made Candiasa, dan I. Made Kirna. 2013. "Pengembangan Perangkat Pembelajaran Matematika Realistik untuk Meningkat-kan Kemampuan Pemecahan Masalah Siswa SMP.” Jurnal Pendidikan dan Pengajaran 46 (2 Juli).

Muzaini, Muhammad. 2016. "Pengaruh pendekatan problem posing terhadap prestasi belajar matematika siswa berdasarkan gaya kognitif." Beta: Jurnal Tadris Matematika 9 (2): 161-79.

Ngaeni, Evi Nur, dan Abdul Aziz Saefudin. 2017. "Menciptakan Pembelajaran Matematika yang Efektif Dalam Pemecahan Masalah Matematika Dengan Model pembelajaran Problem Posing." Jurnal Aksioma 6 (2): 264-74.

Permatasari, Gilang Anjar, Rahayu Budhiati Veronica, dan Bambang Eko Susilo. 2013. "Keefektifan Pembelajaran Problem Posing dengan Pendekatan PMRI Terhadap Kemampuan Berpikir Kreatif Siswa." Unnes Journal of Mathematics Education 2 (2).

Persada, Alif Ringga. 2014. "Pengaruh Pendekatan Problem Posing Terhadap Kemampuan Komunikasi Matematika Siswa Kelas VII." Eduma: Mathematics Education Learning and Teaching 3 (1).

Prastawa, Faradika Ratria. 2013. "Persepsi Guru Pendidikan Jasmani Sekolah Menengah Atas Negeri Se-Kota Yogyakarta Tentang Penilaian Domain Afektif." Jurnal Pendidikan Jasmani Indonesia 9 (2). 
Rufaidah, Anna. 2015. "Pengaruh intelegensi dan minat siswa terhadap putusan pemilihan jurusan." Faktor Jurnal Ilmiah Kependidikan 2 (2).

Sari, Linda Lia. 2013. Pengaruh Pendekatan Problem Posing Terhadap Kemampuan Komunikasi Matematika Siswa Kelas VII MTs Negeri Karangampel. Skripsi. Tidak diterbitkan. Cirebon: IAIN Syekh Nurjati Cirebon.

Setyorini, U., S. E. Sukiswo, dan B. Subali. 2011a. "Penerapan model problem based learning untuk meningkatkan kemampuan berpikir kritis siswa SMP.” Jurnal Pendidikan Fisika Indonesia 7 (1).

2011b. "Penerapan model problem based learning untuk meningkatkan kemampuan berpikir kritis siswa SMP.” Jurnal Pendidikan Fisika Indonesia 7 (1).

Suryani, Lilik Budi, Agung Nugroho Catur Saputro, dan Kus Sri Martini. 2015. "Implementasi Model Pembelajaran Problem Posing Dilengkapi LKS Untuk Meningkatkan Kemampuan Analisis dan Prestasi Belajar Materi Konsep Mol Siswa Kelas X SMA N 8 Surakarta Tahun Pelajaran 2013/2014.” Jurnal Pendidikan Kimia 4 (4): 186-92.

Zaura, Bintang, dan Tuti Zubaidah. 2018. "Pengaruh Minat dan Cara Belajar Terhadap Hasil Belajar Matematika Pada Siswa Kelas VIII SMP Inshafuddin Banda Aceh.” Jurnal Geuthèe: Penelitian Multidisiplin 1 (1): 83-90. 